\title{
Triazole-Au(I) complex as chemoselective catalyst in promoting propargyl ester rearrangements
}

\author{
Dawei Wang, Yanwei Zhang, Rong Cai and Xiaodong Shi ${ }^{*}$
}

\author{
Letter \\ Address: \\ Department of Chemistry, West Virginia University, Morgantown, WV \\ 26506, USA

\section{Email:} \\ Xiaodong Shi - Xiaodong.Shi@mail.wvu.edu \\ * Corresponding author \\ Keywords: \\ allene; chemoselectivity; gold catalysis; ligand effect; organometallic
}

Beilstein J. Org. Chem. 2011, 7, 1014-1020.

doi:10.3762/bjoc.7.115

Received: 23 April 2011

Accepted: 06 July 2011

Published: 25 July 2011

This article is part of the Thematic Series "Gold catalysis for organic synthesis".

Guest Editor: F. D. Toste

(C) 2011 Wang et al; licensee Beilstein-Institut.

License and terms: see end of document.

\begin{abstract}
Triazole-Au (TA-Au) catalysts were employed in several transformations involving propargyl ester rearrangement. Good chemoselectivity was observed, which allowed the effective activation of the alkyne without affecting the reactivity of the allene ester intermediates. These results led to the investigation of the preparation of allene ester intermediates with TA-Au catalysts under anhydrous conditions. As expected, the desired 3,3-rearrangement products were obtained in excellent yields (generally $>90 \%$ yields with $1 \%$ loading). Besides the typical ester migrating groups, carbonates and carbamates were also found to be suitable for this transformation, which provided a highly efficient, practical method for the preparation of substituted allenes.
\end{abstract}

\section{Introduction}

The past decade has seen rapid growth in the use of homogeneous gold catalysis for conducting powerful organic transformations [1-9]. Like many other transition metal complexes, the reactivity of gold catalysts greatly depends on the nature of the ligands coordinating with the metal cations [10-15]. Of the two typical oxidation states, $\mathrm{Au}(\mathrm{I})$ and $\mathrm{Au}(\mathrm{III})$, more studies have been focused on the former cation due to the easier preparation of the catalyst and better pre-catalyst stability. It is currently accepted by the research community that $\mathrm{Au}(\mathrm{I})$ complexes adopt one of two coordination sites with $180^{\circ}$ linear geometry (Scheme 1) (although some exceptions exist). The actual cata- lysts involved in alkyne and alkene activation are of the type $[\mathrm{L}-\mathrm{Au}]^{+}$, with the open coordination site on the opposite side of the ligand (L) for substrate binding [5,6]. The recent success in obtaining the complexes of the alkyne-coordinated $[\mathrm{L}-\mathrm{Au}]^{+}$, reported by Toste and coworkers, greatly supported this mechanistic model [16]. Generally, the $\mathrm{PR}_{3}$ compounds can be applied as the ligand in $\mathrm{Au}(\mathrm{I})$ catalysis. The recent development of N-heterocyclic carbene (NHC) derivatives has significantly expanded the choice of ligands by improving the catalyst stability through metal-ligand backbonding [17-20]. To access the active catalyst $[\mathrm{L}-\mathrm{Au}]^{+}$, stable precursors $\mathrm{L}-\mathrm{Au}-\mathrm{X}$ or 


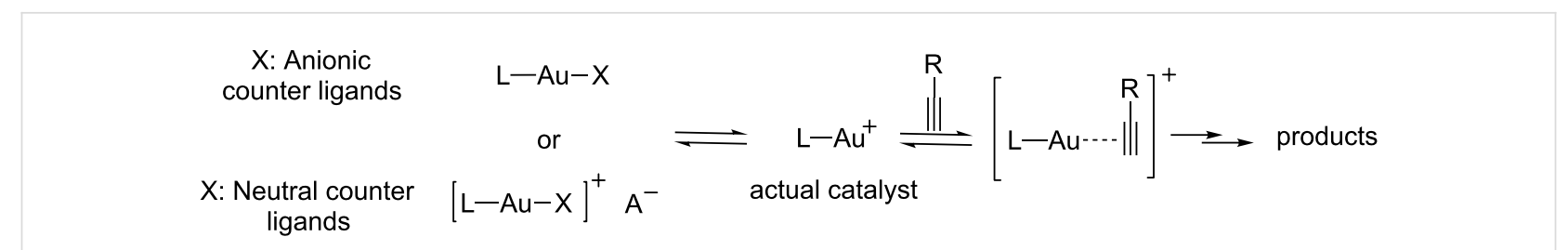

Scheme 1: The counter ligands, an important factor in $\mathrm{Au}(\mathrm{I})$ catalysis.

$[\mathrm{L}-\mathrm{Au}-\mathrm{X}]^{+} \cdot \mathrm{A}^{-}$were typically used. While the ligands (L) are certainly considered critical in gold catalysis, more and more attention have been paid to the evaluation of whether the choice of counter ligand " $\mathrm{X}$ " can be used to adjust the overall catalyst reactivity.

The propargyl ester rearrangement was considered as one of the most important reaction modes in the $\mathrm{Au}(\mathrm{I})$ promoted transformation [21-31]. Recent experimental and computational mechanistic studies revealed the 3,3-rearrangement to form the allene ester intermediate $[32,33]$ as the key step in this transformation (Scheme 2a) [34]. Both experimental and theoretical investigations confirmed the reversibility between allene and propargyl ester due to effective activation of both functional groups by the $\mathrm{Au}(\mathrm{I})$ catalysts. As a result, it was extremely challenging to obtain the allene intermediates with good yields. Many strategies have been developed to make the $\mathrm{Au}(\mathrm{I})$-activated allene esters react with other proper substrates, forming interesting new products in a cascade fashion. The indene synthesis (Scheme 2b), reported by Nolan and coworkers, is one good example highlighting the importance of the cascade process [35].

As shown in Scheme $2 b$, with the $[\operatorname{IPr}-\mathrm{Au}]^{+}$catalyst, only trace amount of the allene 2a was obtained. The major product derived from the Friedel-Crafts addition of the aromatic ring to the gold activated allene. Therefore, selective activation of the alkyne over the allene was considered as a significant challenge in gold catalysis.

\section{Results and Discussions}

Recently, our group reported the synthesis and characterization of the 1,2,3-triazole [36-40] coordinated gold(I) complexes. As revealed by the X-ray crystal structures (Scheme 3 ), both neutral and anionic triazoles can coordinate with $\mathrm{Au}(\mathrm{I})$ cation, forming stable TA-Au complexes [41].

The preparation of these complexes was very straightforward. Simply treating the $\mathrm{NH}$-triazoles with $\mathrm{PPh}_{3} \mathrm{AuCl}$ in methanol under basic conditions $\left(\mathrm{K}_{2} \mathrm{CO}_{3}, 1\right.$ equiv) at room temperature gave the neutral TA-Au-1 in $>90 \%$ yield. The "cationic" complex TA-Au-2 was prepared either from the addition of HOTf to $\mathrm{TA}-\mathrm{Au}-1$ or by the reaction between $\mathrm{PPh}_{3} \mathrm{Au}-\mathrm{OTf}$ (prepared from $\mathrm{PPh}_{3}-\mathrm{Au}-\mathrm{Cl}$ and $\mathrm{AgOTf}$ ) and benzotriazole. Both complexes were stable and could be further purified by recrystallization to ensure no extra $\mathrm{Ag}^{+}$or acid in the catalysts. The crystal structures revealed nearly identical $\mathrm{Au}-\mathrm{P}$ bond length for both the anionic and neutral triazole coordinated $\mathrm{Au}(\mathrm{I})$ complexes. The longer $\mathrm{Au}-\mathrm{N}$ bond in TA-Au-2 implies that the neutral triazole dissociates more easily to release the coordination site for substrate activation. This new class of compounds offers improved thermal stability and substrate stability in the

(a) Equillibrium between gold activated alkyne and allene<smiles>[R]C#C[14CH][14CH2][14CH]([R])OC([R])=O</smiles><smiles>[R]C(=O)OC([R])=C([Y19])[Y19]</smiles>

(b) Indene synthesis: Quenching of the allene by benzene<smiles>CC(=O)OC(C#CBr)c1ccccc1</smiles>

1a 3a, $92 \%$<smiles>CC(=O)OC(=C=Cc1ccccc1)Cc1ccccc1</smiles>

2a, trace 


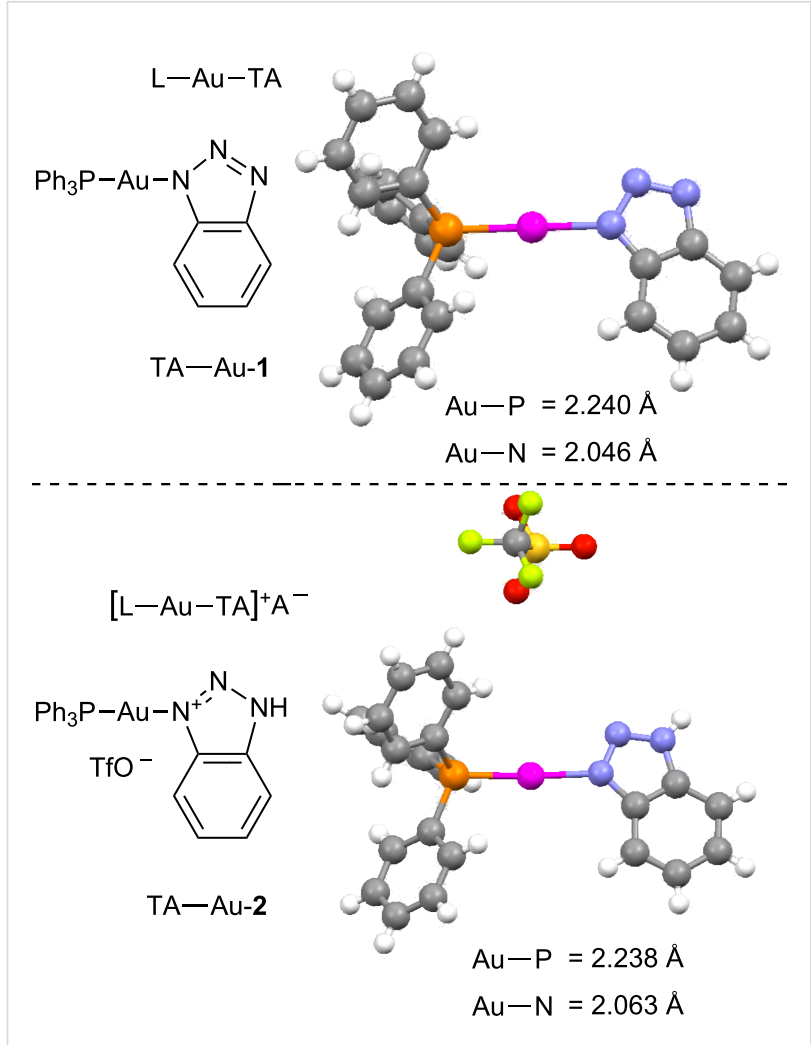

Scheme 3: X-ray crystal structures of the two different types of 1,2,3triazole-Au complexes.

gold(I) promoted hydroamination and Hashmi phenol synthesis [42], which makes them interesting novel catalysts in the field of gold catalysis. One particular new development of the $\mathrm{TA}-\mathrm{Au}$ catalysis that attracted our attention was the synthesis of $\alpha$-iodoenone from propargyl esters (Scheme 4a) [43].

As indicated in Scheme $4 \mathrm{a}$, the typical $[\mathrm{L}-\mathrm{Au}]^{+}$catalyst promoted the sequential rearrangement and iodination, giving the thermally, dynamically stable $(Z)$-isomer [44-46]. The cationic TA-Au catalyst, on the other hand, produced the kinetically favored $(E)$-isomer. Notably, treating the allene ester $\mathbf{2 a}$ with NIS gave the $(E)$-isomer as the dominant product. These results imply that the allene iodination should favor the formation of the $(E)$-isomer (Scheme $4 \mathrm{~b})$. The typical $[\mathrm{L}-\mathrm{Au}]^{+}$catalyst not only promoted the propargyl ester 3,3-rearrangement, but also influenced the allene reactivity, probably through gold catalyzed allene activation. The fact that TA-Au gave the dominant $(E)$-isomers strongly suggests that these complexes may be applied as the chemoselective catalyst in alkyne activation over allene. The reactions of propargyl ester 1a with TA-Au catalysts were then investigated as shown in Figure 1.

As expected, with the cationic catalyst TA-Au-2 or TA-Au-3, the allene ester $\mathbf{2 a}$ was formed in excellent yields (1\% loading, $91 \%$ yield). It is important to note here, that indene $\mathbf{3 a}$ was not observed even after $48 \mathrm{~h}$ reaction time, thus indicating excellent chemoselectivity of the triazole coordinated gold complexes. Various propargyl esters were synthesized to test the reaction substrate scope. The results are summarized in Table 1.

As shown in Table 1, the transformation proceeded smoothly with substrates having both an aromatic group on the propargyl side and an aliphatic group on the alkyne side (entries 1-6). The desired allene products were formed in excellent yields, with $1 \%$ catalyst loading. The electronic density on the aromatic ring did not have a strong impact on the transformation: Both electron donating and electron-withdrawing groups were suitable for the reaction. Again, no indene by-products were observed in any of the tested cases, even with the electron-enriched $p$-OMe substituted alkyne 1d. These results highlighted the excellent chemoselective nature of the TA-Au catalyst.

The terminal alkyne 1i did not give any product when treated with TA-Au catalyst, even after an extended reaction time

(a) Formation of $(E)$ - $\alpha$-haloenones with TA-Au, (Z)-isomers with $\mathrm{Au}\left(\mathrm{PPh}_{3}\right) \mathrm{NTf}_{2}$

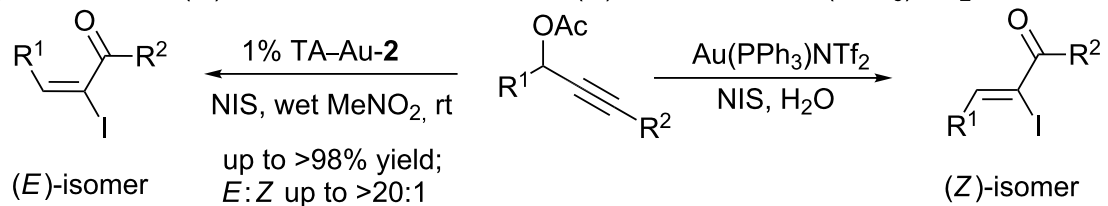

(b) Formation of kinetically favored $(E)$-isomers

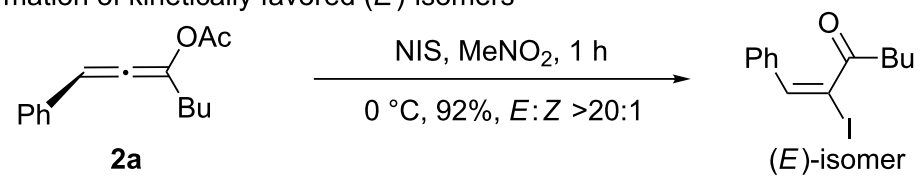




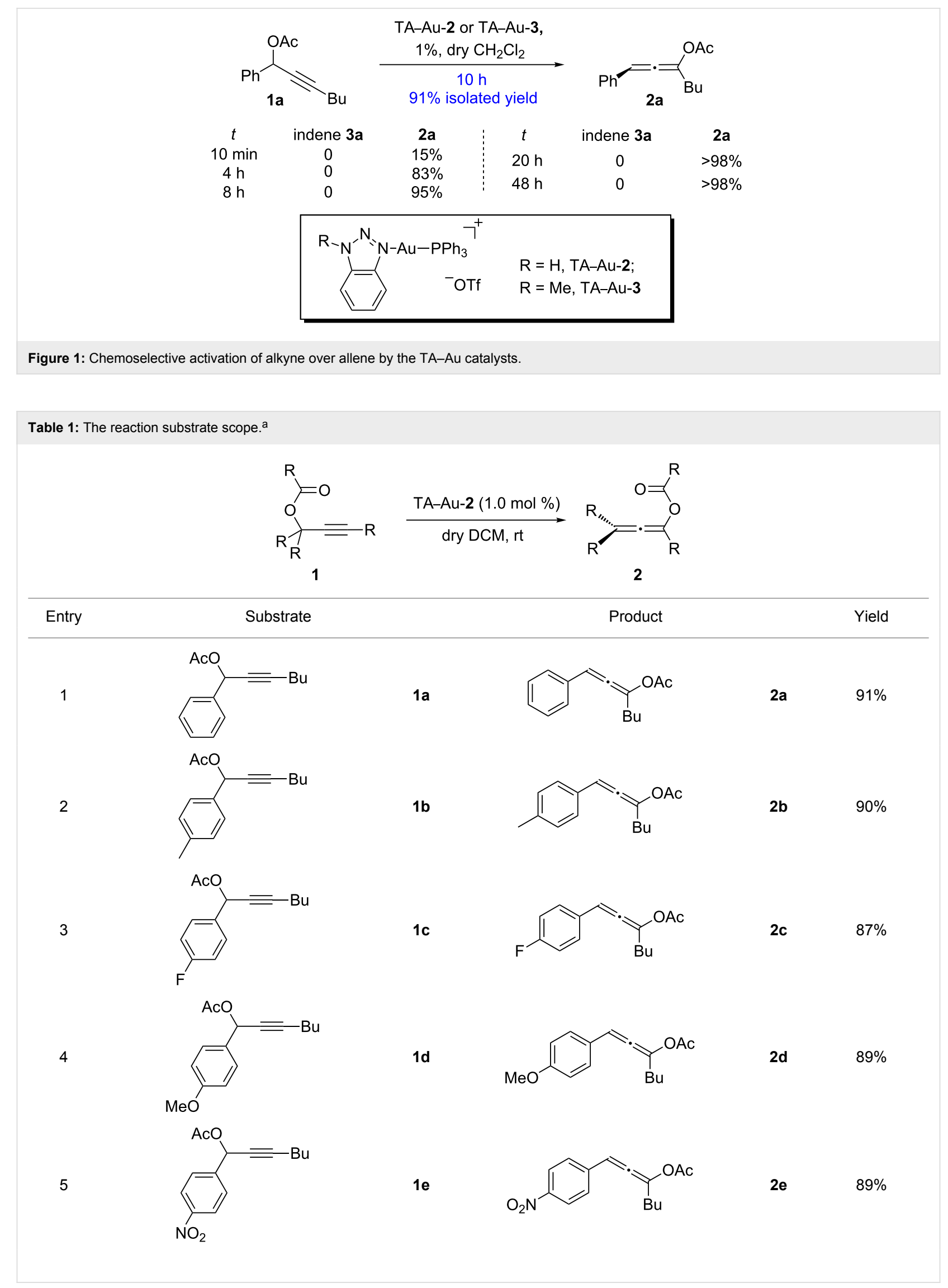


Table 1: The reaction substrate scope. ${ }^{a}$ (continued)

6<smiles>CC(C)(C)OC(C#CC1CC1)c1ccccc1</smiles>

$1 f$<smiles>CC(=O)OC(=C=Cc1ccccc1)C1CC1</smiles>

$2 f$ $85 \%$

Substrates that did not form the desired allenes ${ }^{b}$

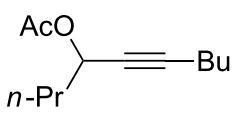

$1 \mathrm{~g}$

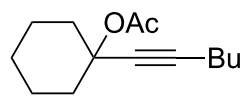

$1 \mathrm{~h}$

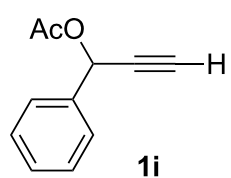

$1 \mathrm{i}$

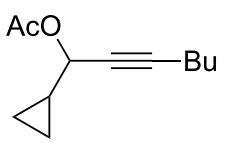

$1 \mathrm{j}$

${ }^{a}$ General reaction conditions: $1(0.25 \mathrm{mmol})$ and TA-Au-2 $(1.0 \mathrm{~mol} \%)$ in dry DCM $(2.5 \mathrm{~mL})$, the reactions were monitored by TLC (2-10 h), rt. bTA-Au-1, TA-Au-2 and TA-Au-3 did not catalyze the reaction under the standard conditions.

$(24 \mathrm{~h})$. This was probably caused by the preferred $1,2-$ rearrangement with the formation of a vinyl-Au intermediate. The aliphatic propargyl esters $(\mathbf{1 g}, \mathbf{1 h})$ also did not give any desired allene products (enones from hydrations were produced after a long reaction time, $24-48 \mathrm{~h}$; the crude NMR of the reaction mixtures did not show any allene products). This may be caused by the high reactivity of the corresponding aliphatic allenes under the reaction conditions (activated by TA-Au) and the overall better stability of the propargyl ester compared to the aliphatic substituted allenes (equilibrium favored the starting material). The reaction of cyclopropyl substituted propargyl ester $\mathbf{1 j}$ with the TA-Au catalyst gave a complex reaction mixture, which suggests possible ring opening and sequential cyclization as reported previously [47]. Overall, this study suggests that the propargyl ester rearrangement to form allene is highly substrate dependent. This could either be due to the similar reactivity of the alkyne and the allene (giving an equilibrium state favoring the alkyne over the allene) or it be could be due to a preferred alternative migration path (2,3-migration versus 3,3-migration). In any case, the TA-Au catalyst clearly displayed the interesting chemoselectivity, if the reaction could occur. To study the feasibility of this migration, we then investigated migrating groups other than esters. The results are summarized in Table 2.

As indicated in Table 2, carbonates (entries 1-5) and carbamate (entry 6) were also suitable for this transformation. Compared to the allene-acetates, the allene-carbonates and allene-carba-

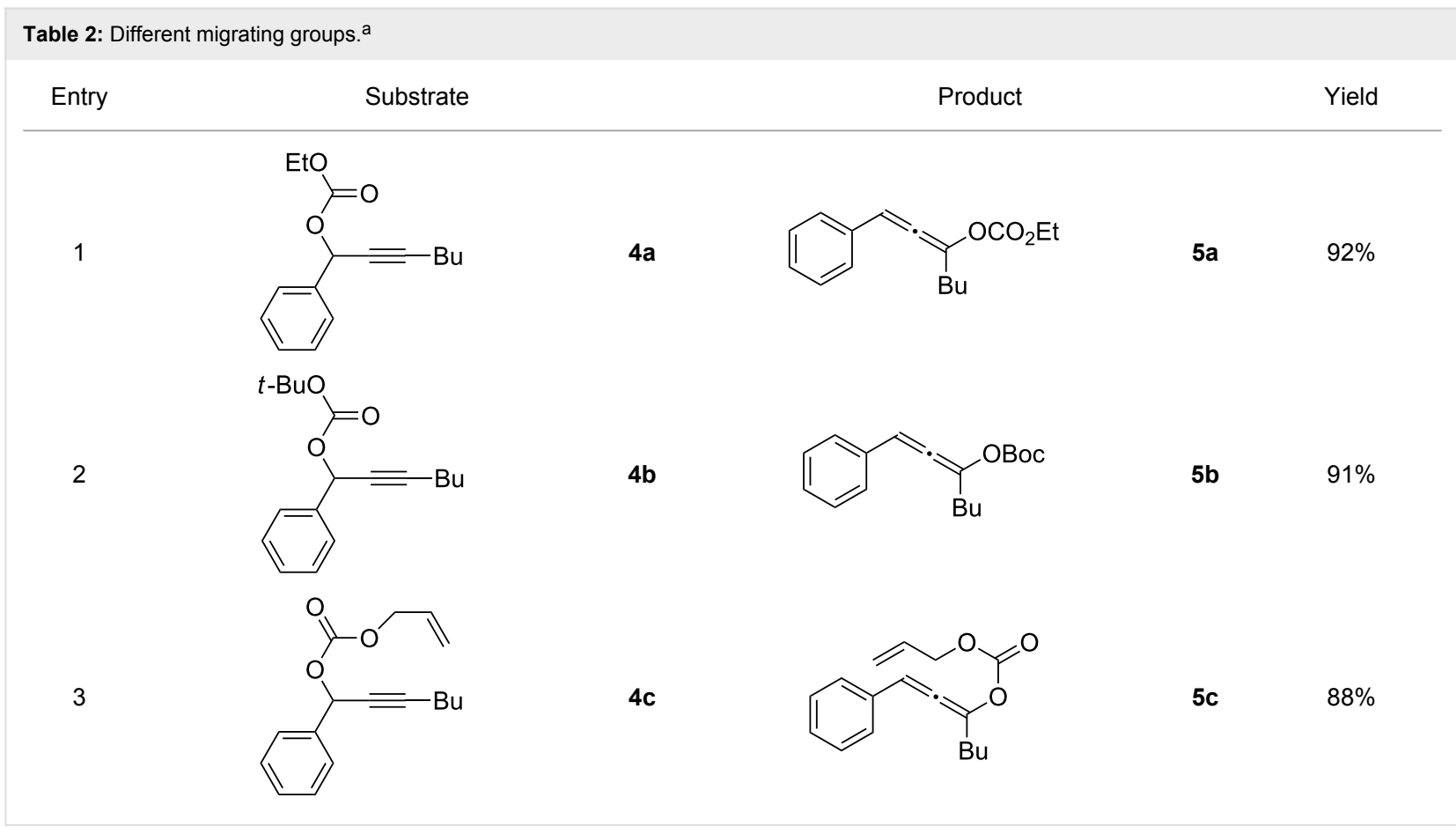


Table 2: Different migrating groups. ${ }^{a}$ (continued)

4<smiles>CCOC(=O)OC(C#CBr)c1cccc(C(C#CCc2ccccc2)OC(=O)OCC)c1</smiles>

6<smiles>O=C(Nc1ccccc1)OC(C#CBr)c1cccc([N+](=O)[O-])c1</smiles>

4d<smiles>CCOC(=O)OC(Br)=C=Cc1cccc([N+](=O)[O-])c1</smiles>

$5 d$

$92 \%$<smiles>CC(C)(C)Oc1cccc(C=C=C(CBr)[N+](=O)[O-])c1</smiles>

$5 e$

$89 \%$<smiles>NC(=O)OC(=C=Cc1cccc([N+](=O)[O-])c1)CBr</smiles>

$5 f$

$85 \%$

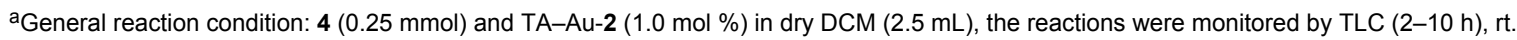

mates were more stable in water. Notably, although the alkene was considered as a readily reactive functional group in gold catalysis, the substrate $\mathbf{4 c}$ was suitable for this transformation, giving the desired allene-ene $\mathbf{5 c}$ in excellent yield.

\section{Conclusion}

In this letter, we reported the application of triazole-coordinated gold(I) complexes as the effective catalysts for the promotion of the propargyl ester, carbonate and carbamate 3,3rearrangement for the synthesis of the corresponding substituted allene derivatives. The chemoselective nature of the TA-Au catalysts was clearly demonstrated, which makes them an interesting class of new catalysts for promoting organic transformations. The application of the allene-carbonates and allene-carbamates as building blocks for development of new synthetic methodologies is currently underway in our group.

\section{Supporting Information}

\section{Supporting Information File 1}

General methods, characterization data and NMR spectra of synthesized compounds.

[http://www.beilstein-journals.org/bjoc/content/ supplementary/1860-5397-7-115-S1.pdf]

\section{Acknowledgements}

We thank the NSF (CHE-0844602), WVU-PSCoR for financial support.

\section{References}

1. Hashmi, A. S. K.; Rudolph, M. Chem. Soc. Rev. 2008, 37, 1766-1775. doi:10.1039/b615629k

2. Gorin, D. J.; Sherry, B. D.; Toste, F. D. Chem. Rev. 2008, 108 3351-3378. doi:10.1021/cr068430g

3. Arcadi, A. Chem. Rev. 2008, 108, 3266-3325. doi:10.1021/cr068435d

4. Jiménez-Núñez, E.; Echavarren, A. M. Chem. Rev. 2008, 108, 3326-3350. doi:10.1021/cr0684319

5. Hashmi, A. S. K. Chem. Rev. 2007, 107, 3180-3211. doi:10.1021/cr000436x

6. Fürstner, A.; Davies, P. W. Angew. Chem., Int. Ed. 2007, 46, 3410-3449. doi:10.1002/anie.200604335

7. Jiménez-Núñez, E.; Echavarren, A. M. Chem. Commun. 2007, 333-346. doi:10.1039/B612008C

8. Zhang, L.; Sun, J.; Kozmin, S. A. Adv. Synth. Catal. 2006, 348, 2271-2296. doi:10.1002/adsc.200600368

9. Hashmi, A. S. K.; Hutchings, G. J. Angew. Chem., Int. Ed. 2006, 45, 7896-7936. doi:10.1002/anie.200602454

10. Hashmi, A. S. K.; Rudolph, M.; Huck, J.; Frey, W.; Bats, J. W.; Hamzić, M. Angew. Chem., Int. Ed. 2009, 48, 5848-5852. doi:10.1002/anie.200900887

11. Hashmi, A. S. K.; Loos, A.; Littmann, A.; Braun, I.; Knight, J.; Doherty, S.; Rominger, F. Adv. Synth. Catal. 2009, 351, 576-582. doi:10.1002/adsc.200800681

12. Hashmi, A. S. K.; Salathé, R.; Frey, W. Chem.-Eur. J. 2006, 12, 6991-6996. doi:10.1002/chem.200600533

13. Hashmi, A. S. K.; Blanco, M. C.; Kurpejović, E.; Frey, W.; Bats, J. W. Adv. Synth. Catal. 2006, 348, 709-713. doi:10.1002/adsc.200606012

14. Hashmi, A. S. K.; Weyrauch, J. P.; Kurpejović, E.; Frost, T. M.; Miehlich, B.; Frey, W.; Bats, J. W. Chem.-Eur. J. 2006, 12, 5806-5814. doi:10.1002/chem.200501268

15. Carrettin, S.; Blanco, M. C.; Corma, A.; Hashmi, A. S. K. Adv. Synth. Catal. 2006, 348, 1283-1288. doi:10.1002/adsc.200606099 
16. Shapiro, N. D.; Toste, F. D. Proc. Natl. Acad. Sci. U. S. A. 2008, 105, 2779-2782. doi:10.1073/pnas.0710500105

17. de Frémont, P.; Scott, N. M.; Stevens, E. D.; Nolan, S. P. Organometallics 2005, 24, 2411-2418. doi:10.1021/om050111c

18. Díez-González, S.; Marion, N.; Nolan, S. P. Chem. Rev. 2009, 109, 3612-3676. doi:10.1021/cr900074m

19. Marion, N.; Nolan, S. P. Acc. Chem. Res. 2008, 41, 1440-1449. doi:10.1021/ar800020y

20. Díez-González, S.; Nolan, S. P. Acc. Chem. Res. 2008, 41, 349-358. doi:10.1021/ar7001655

21. Zhang, L. J. Am. Chem. Soc. 2005, 127, 16804-16805. doi:10.1021/ja056419c

22. Zhang, L.; Wang, S. J. Am. Chem. Soc. 2006, 128, 1442-1443. doi:10.1021/ja057327q

23. Buzas, A.; Istrate, F.; Gagosz, F. Org. Lett. 2006, 8, 1957-1959. doi:10.1021/ol0606839

24. Wang, S.; Zhang, L. Org. Lett. 2006, 8, 4585-4587. doi:10.1021/ol0618151

25. Wang, S.; Zhang, L. J. Am. Chem. Soc. 2006, 128, 8414-8415. doi:10.1021/ja062777j

26. Buzas, A.; Gagosz, F. J. Am. Chem. Soc. 2006, 128, 12614-12615. doi:10.1021/ja064223m

27. Wang, S.; Zhang, L. J. Am. Chem. Soc. 2006, 128, 14274-14275. doi:10.1021/ja066220f

28. Marion, N.; Nolan, S. P. Angew. Chem., Int. Ed. 2007, 46, 2750-2752. doi:10.1002/anie.200604773

29. Marco-Contelles, J.; Soriano, E. Chem.-Eur. J. 2007, 13, 1350-1357. doi:10.1002/chem.200601522

30. Barluenga, J.; Riesgo, L.; Vicente, R.; Lopéz, L. A.; Tomás, M. J. Am. Chem. Soc. 2007, 129, 7772-7773. doi:10.1021/ja072864r

31.Shi, F.-Q.; Li, X.; Xia, Y.; Zhang, L.; Yu, Z.-X. J. Am. Chem. Soc. 2007, 129, 15503-15512. doi:10.1021/ja071070+

32. Saucy, R.; Marbet, R.; Lindlar, H.; Isler, O. Helv. Chim. Acta 1959, 42, 1945-1955. doi:10.1002/hlca.19590420624

33. Cherbuliez, E.; Moll, H.; Baehler, B. R.; Rabinowitz, J. Helv. Chim. Acta 1967, 50, 1154-1158. doi:10.1002/hlca.19670500422

34. Wang, D.; Gautam, L. N. S.; Bollinger, C.; Harris, A.; Li, M.; Shi, X. Org. Lett. 2011, 13, 2618-2621. doi:10.1021/ol200714h

35. Marion, N.; Díez-González, S.; de Fremont, P.; Noble, A. R.; Nolan, S. P. Angew. Chem., Int. Ed. 2006, 45, 3647-3650. doi:10.1002/anie.200600571

36. Sengupta, S.; Duan, H.; Lu, W.; Petersen, J. L.; Shi, X. Org. Lett. 2008, 10, 1493-1496. doi:10.1021/ol8002783

37. Chen, Y.; Liu, Y.; Petersen, J. L.; Shi, X. Chem. Commun. 2008, 3254-3256. doi:10.1039/b805328f

38. Liu, Y.; Yan, W.; Chen, Y.; Petersen, J. L.; Shi, X. Org. Lett. 2008, 10 , 5389-5392. doi:10.1021/ol802246q

39. Duan, H.; Yan, W.; Sengupta, S.; Shi, X. Bioorg. Med. Chem. Lett. 2009, 19, 3899-3902. doi:10.1016/j.bmcl.2009.03.096

40. Yan, W.; Wang, Q.; Chen, Y.; Petersen, J. L.; Shi, X. Org. Lett. 2010, 12, 3308-3311. doi:10.1021/ol101082v

41. Duan, H.; Sengupta, S.; Petersen, J. L.; Akhmedov, N. G.; Shi, X. J. Am. Chem. Soc. 2009, 131, 12100-12102. doi:10.1021/ja9041093

42. Chen, Y.; Yan, W.; Akhmedov, N. G.; Shi, X. Org. Lett. 2010, 12, 344-347. doi:10.1021/ol902680k

43. Wang, D.; Ye, X.; Shi, X. Org. Lett. 2010, 12, 2088-2091. doi:10.1021/ol100576m

44. Yu, M.; Zhang, G.; Zhang, L. Org. Lett. 2007, 9, 2147-2150. doi:10.1021/ol070637o
45. Ye, L.; Zhang, L. Org. Lett. 2009, 11, 3646-3649. doi:10.1021/ol901346k

46. Yu, M.; Zhang, G.; Zhang, L. Tetrahedron 2009, 65, 1846-1855. doi:10.1016/j.tet.2008.11.107

47. Mauleón, P.; Krinsky, J. L.; Toste, F. D. J. Am. Chem. Soc. 2009, 131, 4513-4520. doi:10.1021/ja900456m

\section{License and Terms}

This is an Open Access article under the terms of the Creative Commons Attribution License

(http://creativecommons.org/licenses/by/2.0), which permits unrestricted use, distribution, and reproduction in any medium, provided the original work is properly cited.

The license is subject to the Beilstein Journal of Organic Chemistry terms and conditions:

(http://www.beilstein-journals.org/bjoc)

The definitive version of this article is the electronic one which can be found at: doi:10.3762/bjoc.7.115 